\title{
Miriam Grunstein*
}

\section{La cultura va al mercado. El patrimonio cultural en el tráfico comercial}

SUMARIO: LA ESENCIA DE FRIDA EN EL AIRE. FRIDA SE FUGA A LA REALIDAD VIRTUAL. "EL RESPETO A LA HAMBURGUESA AJENA ES LA PAZ", OAXACA VS. RONALD MCDONALD. LA LEY DE LA SELVA: LA TRISTE HISTORIA DE UN CASINO. LA DEFENSA DEL VETERANO. EL TORO ES PATRIMONIO.

\begin{abstract}
"Los tiempos de las oposiciones binarias se acabaron. Vivimos la era donde desaparecen las relaciones entre contrarios y éstos entran, uno con otro, en un fluido devenir. Lo alto y lo bajo son uno solo; lo ajeno y lo propio no son de nadie; y lo eterno y lo efímero parpadean en un mismo signo de neón ${ }^{1} . "$
\end{abstract}

Con esta frase, y otras, algunos saludaron a la postmodernidad en los años ochenta. En los cafés de los barrios universitarios de los grandes centros urbanos de Europa y Estados Unidos, y en menor proporción en América Latina, el discurso sobre el aplanamiento de todo se volvió dominante. Fuera quedaban los modelos jerárquicos, escalonados, nivelados, arbóreos, genealógicos, genésicos, cronológicos y quien se atreviera a sugerir que existían aún "relaciones entre opuestos" corría el riego de perder,

* Licenciada en Derecho y Doctora en Letras. Profesora de la Maestría en Derecho Administrativo y de la Regulación ITAM. Abogada de Thompson \& Knight LLP, México.

${ }^{1}$ Ver Sebastian Kelev-Chien, "On plastic bones and archeology», New Foundland, Green Stone Press, 1988. 
no sólo su silla en el café, sino también la voz en ciertos foros académicos de moda.

De entre las lecturas de aquel momento, Mil Mesetas de Gilles Deleuze y Feliz Guattari partió brecha hacia tierras nuevas. Ya la figura de la meseta, como nueva visión del mundo, como nuevo modelo jurídico $y$ político, era muy sugerente: superficie plana, abierta y extendida, sin límites visibles. Desde la meseta, lejana era la sombra de la pirámide — vestigio de la rancia arqueología jurídico-política - cuya estructura evoca sistemas de castas, capas sociales, jerarquías, estratos, relaciones de suprasubordinación. Con sólo asestarle un golpe a la base de la pirámide, quedaba sólo la meseta, superficie abierta a todos en un mismo plano.

En este nuevo foro se oyeron las llamadas para los primeros actos de la liberalización de los intercambios comerciales y, junto con ellos, los intercambios culturales. En el ámbito político y comercial de la relación entre México y Estados Unidos, se comenzaba a fraguar el Tratado de Libre Comercio de América del Norte (del cual Canadá también es parte); en 1986, México entraría a ser parte del Acuerdo General del GATT — ahora OMC - y devenía de nación rica pero vulnerable a Estado rudo y competitivo. El dinamismo del México "liberalizado" habría de sentirse al verlo correr por el mundo, con productos, con atletas, profesionistas, científicos y, como la joya de la corona, con un patrimonio cultural como pocos.

Así, en 1990, los autobuses urbanos de la ciudad de Nueva York pululaban por doquier con carteles que anunciaban que en el Museo de Arte Metropolitano (MAM) de la Ciudad se estrenaría la monumental exposición de arte mexicano llamada “30 siglos de esplendor”. Por la quinta avenida pasaban mujeres, ya no vestidas por Coco Chanel o Dior, sino con atuendos de Tehuana o de china poblana. Su modelo a seguir las pasaba de largo adusta, sin mirarlas: era el autorretrato de Frida Kahlo, estampado en el flanco de un autobús. Con la llegada de la monumental exposición comenzaba un espontáneo y disperso carnaval entre distintos círculos de la élite cultural citadina. La presencia del patrimonio cultural mexicano en la gran jungla de asfalto se sentía en colores, en caras, en aromas y en texturas. Ese mismo año, Octavio Paz, poeta mexicano, pero conocido por su cosmopolitismo y por la "universalidad" de su creación artística, fue laureado con el Premio Nobel.

Algo de México — partes muy selectas de él- se desplazaba al mundo de los fuertes. Por usar el término de Deleuze y Guattari, Mexico se reterritorializó en las mecas de la cultura global y nubló, al menos en la percepción de un manojo de privilegiados, la oposición binaria entre norte y sur, nosotros y ellos, los ricos y los pobres, los fuerte y los débiDA-2005, núm. 273. MIRIAM GRUNSTEIN. 8. La cultura va al mercado. El patrimonio cultu... 
les. La euforia del intercambio cultural y el acceso a objetos "exóticos" pero plenamente "apropiables" por una población cosmopolita daba la sensación de gran libertad, de viajar a gran velocidad por una súper carretera que rodeaba al mundo, de vivir tiempos y espacios lejanos en un solo instante y en un solo lugar. El comercio y la cultura andaban sueltos, de la mano, como un par de lúdicos diablillos tirando barreras.

Como casi todo, tirar barreras tiene sus reglas. Al hablar sobre la relación entre cultura y comercio, bien dice George Yudice que "los términos 'libre comercio' y 'cultura' no tienen significados en modo alguno transparentes. Por ejemplo, el calificativo 'libre' sugiere que en los acuerdos gubernamentales e internacionales se juzga el comercio como algo irrestricto (...) El libre comercio es todo menos irrestricto. Requiere cuidadosas gestiones, tal como lo comprueban los cientos de protocolos, declaraciones y artículos que constituyen los tratados comerciales ${ }^{2}$."

Que la libertad comercial sea un fenómeno que tiene sus propias reglas se percibe aún más cuando llega a ámbitos de regulación que, al rozarlos, se resisten a ella. Por mucho que hayamos decidido desechar la idea de las oposiciones binarias, por ser entusiastas de Deleuze y Guattari, la regulación protectora del patrimonio cultural mexicano se resiste a la idea de que éste sea objeto del comercio, si bien tampoco es cierto que lo excluye categóricamente del tráfico comercial. Es importante entender que, en México, el grado de circulación comercial y de apropiación privada de los bienes culturales depende de la categoría normativa a la que pertenezcan. En México, como en muchas otras partes, el estado expresa sus celos sobre ciertos bienes a través de las prohibiciones o restricciones que impone sobre su tenencia y circulación comercial. De mayores a menores prohibiciones, en México los bienes culturales que están categóricamente excluidos del comercio son los de la época precolombina o prehispánica (los llamados "monumentos arqueológicos"); luego los bienes correspondientes al siglo IXX hasta nuestros días (los llamados "monumentos históricos y artísticos”) se encuentran bajo un régimen de circulación comercial de menores restricciones pero están lejos de poder circular libremente por el mercado nacional. En cuanto al mercado internacional, ningún objeto del patrimonio cultural mexicano puede ser exportado del país de forma definitiva ${ }^{3}$.

Esto es en cuanto a la libertad de circulación que tienen las piezas originales de los monumentos. Las copias, por otra parte, tienen otro régimen de reproducción para fines comerciales que en México está suje-

${ }^{2}$ Ver George Yudice, El recurso de la cultura. Barcelona, Gedisa, 2002. p. 261.

${ }^{3}$ Ver Miriam Grunstein, Los arrebatos del arte. México, Porrúa, 2006. pp. 36-57. DA-2005, núm. 273. MIRIAM GRUNSTEIN. 8. La cultura va al mercado. El patrimonio cultu... 
to, en lo principal, a la legislación de los Derechos de Autor y también a aquélla en materia de patrimonio cultural. En el primer caso, los titulares de los derechos morales y patrimoniales serán las personas que la ley, o cualquier otro acto o instrumento jurídicos, designen como tales. En cuanto al segundo, es claro que el titular de los derechos de reproducción de las bienes objeto del patrimonio cultural será el Estado, quien pondrá las condiciones bajo las que podrán hacerse reproducciones cuyo fin sea circular en el mercado. La Ley Federal sobre Monumentos y Zonas Arqueológicos, Artísticos e Históricos (LFMMZZ) establece que los monumentos podrán reproducirse para fines comerciales, previo consentimiento de las autoridades competentes, ésto es, el Instituto Nacional de Antropología e Historia (INAH), para los monumentos arqueológicos e históricos; y el Instituto Nacional de Bellas Artes (INBA) para los monumentos artísticos. Por su parte, el Reglamento de la LFMMZZ no establece más requisito para la autorización de la reproducción que el "no menoscabo a su calidad de monumento." Sin embargo, la "ficha de trámite", expedida por el INBA, hace una interpretación de esta frase al establecer que la reproducción de la obra debe ser "sin pretensiones cómicas u ofensivas; sin modificación alguna, en publicaciones o grabaciones que resalten la importancia del arte mexicano y que no se ligue con productos comerciales que induzcan a vicios o dependencias"

Es pertinente mencionar que, mientras que los requisitos de que la reproducción sea fiel y de buena calidad son razonables, además de congruentes con la legislación de derechos de autor mexicana, que la reproducción sea o no considerada "cómica", "ofensiva", o ligada a productos que "induzcan a vicios o dependencias" requiere ya de un juicio netamente subjetivo por parte de la autoridad. Bajo este criterio, el INBA ha negado la autorización de reproducción a R.J Reynolds Tobacco de México para utilizar la imagen del Palacio de Bellas Artes en un anuncio de la marca "Camel", en cuya maqueta se divisaba el Palacio a la sombra de Joe Camel, el cool camello fumador. Más aún, también se negó la autorización para el uso de la imagen del Ángel de la Independencia para un anuncio de papas marca "Sabritas", en el que se caricaturizaba al Ángel comiendo papitas, con los labios fruncidos de placer y las mejillas abultadas, resistiéndose inútilmente a una más. ¿Será porque las "Sabritas" "inducen a vicios" porque "nadie puede comer sólo una"?

${ }^{4}$ Ver www.inba.gob.mx/pdfs/trámites/f7002.pdf.

5 Así dice el «jingle publicitario» que, desde siempre, advierte que estas frituras son adictivas. Ver Miriam Grunstein, op. cit., pp. 66-68.

DA-2005, núm. 273. MIRIAM GRUNSTEINN. 8. La cultura va al mercado. El patrimonio cultu... 


\section{LA ESENCIA DE FRIDA EN EL AIRE}

Curiosamente, en tiempos recientes quien se opuso al uso comercial de imágenes pertenecientes al acerbo del patrimonio cultural de la nación no fue el Estado, el cual en ciertas ocasiones se ha mostrado notoriamente pasivo ante la explotación de imágenes culturales para fines comerciales. Se trata de la línea de perfumes y de ropa femenina que culminó con el triunfo de la que probó ser la titular de los derechos de Propiedad Industrial, que no los derechos de autor, sobre el nombre y la firma de Frida Kahlo. Sobrina y única heredera de los derechos sobre el nombre de la artista, Isolda Pineda Kahlo ${ }^{6}$ demandó se retiraran los productos del comercio. De acuerdo con José Hinojosa, abogado de Pineda Kahlo, esto se debió a que la "calidad de los (demás) productos no resultó ser la adecuada”, por lo que la heredera sólo permitió la venta del perfume El carácter de su esencia. El producto, que se comercializa desde septiembre de 2002, reproduce en su botella la rúbrica de Kahlo y en el empaque la pintura Autorretrato con Espinas.'.

A la oposición de los titulares al uso del nombre de Frida Kahlo, siguió el clamor de opinión pública en contra del uso de las imágenes y nombres de los pintores más afamados de México. En la opinión de las críticas Raquel Tibol, Teresa del Conde y Blanca Garduño, estas reproducciones representan una "vulgarización" de la imagen de ambos creadores $^{8}$ :

"Vulgarizar a Diego y Frida me parece un acto perverso. Si los hijos de Dolores Olmedo y Carlos García Ponce 9 consideran que tiene derecho a denigrar el derecho de los artistas, el Consejo Nacional para la Cultura y las Artes debería tomar cartas en el asunto, ya que es su responsabilidad por estar considerada la obra como Monumento Artístico' , indicó Tibol ${ }^{10}$."

${ }^{6}$ Hija de Cristina, hermana de Frida, Pineda Kahlo es la única persona que puede autorizar el uso del nombre, pseudónimo o firma de la pintora, de acuerdo al artículo 90, fracción XII, de la Ley de Propiedad Industrial que establece que el nombre no puede ser registrado como marca "sin el consentimiento de los interesados o, si han fallecidos, en su orden, del cónyuge, parientes consanguíneos en línea recta y por adopción, y colaterales, ambos hasta el cuarto grado."

7 Ver artículo de Edgar Alejandro Hernández, "Cancelan productos con obra de Frida», en periódico Reforma, 3 de enero de 2003.

${ }^{8}$ Ver Edgar Alejandro Hernández, “Vulgarizan’ a Diego y Frida» en Reforma. 26 de septiembre de 2006.

${ }^{9}$ Fideicomitente y miembro del comité técnico, respectivamente, del Fideicomiso KahloRivera.

10 Ibid.

DA-2005, núm. 273. MIRIAM GRUNSTEIN. 8. La cultura va al mercado. El patrimonio cultu... 
En defensa de su producto, por supuesto, se manifestó Jacqueline Alcalá, presidenta de Godven Internacional. A su juicio, dicho proyecto comercial traerá, al contrario de lo dicho por las críticas, todo un beneficio social ya que, además de estimular los sentidos de hombres y mujeres a través del olfato, se añade otro ingrediente de placer estético y de difusión del arte al poner al alcance del público "las obras en la caja (de los perfumes), para difundir la obra ${ }^{11}$." Insensible a tales argumentos, Teresa del Conde siguió atestando pedradas y señaló un frívolo y vulgar interés económico por parte de todos los implicados en el uso de las obras y de los nombres de los artistas: "Es una cursilada y para nada un homenaje a Diego y Frida. Quién sabe si sus cenizas se removerían en sus respectivas urnas al saberlo, probablemente sí $^{12}$."

Eso difícilmente se sabrá. Lo que sí es información pública son las declaraciones de Jose Luis Pérez Arrendondo, delegado fiduciario especial del Fideicomiso Kahlo-Rivera del Banco de México: "Esta empresa pidió lo derechos de autor para reproducir las pinturas en los empaques de los perfumes y nosotros no tenemos nada que ver con el producto. Si pagan su tarifa no hay problema". Además, "Pérez Arredondo aseguró que 'los recursos que generan este tipo de productos se utilizan para mantener los museos Frida Kahlo (la Casa Azul) y el Museo Anahuacalli (dedicado a Rivera). No creo que este proyecto sea una vulgarización de su obra porque se cuida las reproducciones no vayan en contra de la imagen de los artistas ${ }^{13}$.'

Hasta ahora se ha hecho recuento de la opinión del recién citado delegado del Fideicomiso; también como del abogado de Isolda Pineda Kahlo; de la presidenta de Godven International y de una parte de la opinión pública, a través de las voces por algunos de los críticos de arte de más renombre en México. ¿Qué del INBA? Llama la atención que en los medios no se hayan hecho pública la opinión de la autoridad que tiene encomendada la defensa del patrimonio artístico de México ${ }^{14}$. Al respecto, Blanca Garduño, también crítica de arte, opinó lo siguiente sobre la pasividad de las autoridades:

"El INBA poco tiene que hacer, ya que no ha demostrado su fuerza para controlar y legislar sobre el tema. El mundo ya es dueño de estas imágenes. En

11 Ibid.

12 Ibid.

13 Ibid.

${ }_{14} \mathrm{Al}$ momento de estas entrevistas, se sabía tan sólo que el INBA no había expedido el permiso de reproducción, porque en la solicitud presentada por la empresa faltaba aún entregar copia de la autorización proveniente del Fideicomiso.

DA-2005, núm. 273. MIRIAM GRUNSTEIN. 8. La cultura va al mercado. El patrimonio cultu... 
todas partes ${ }^{15}$ encontramos playeras, tazas, botones que reproducen obra de artistas famosos. Si el dueño de las obras de Diego y Frida da el permiso, el INBA se queda mudo, ya que tiene pocos argumentos para negarse ${ }^{16}$."

Fuera de toda especulación sobre la opinión de la autoridad sobre los productos, de lo que se tiene certeza es que el INBA otorgó a Godven International el permiso de reproducción de monumento artístico número 22/97 para imprimir las imágenes de los cuadros antes mencionados en las cajas de los perfumes; en "pantalones de mezclilla marca DS Jeans con botones remaches y bolsas traseras que sirven de soporte a la firma y la obra de la artista"; "playeras de algodón marca DS Jeans con la firma bordada en el antebrazo y pecho del costado izquierdo"; y en "platones de porcelana Rosenthal con filo de oro de 24 kilates que reproduce obra y firma de pintora ${ }^{17}$."

Por lo visto, el INBA no consideró que descansar las pinturas de Frida Kahlo y Diego Rivera en los pechos y glúteos de jóvenes y viejos no era constitutivo de un "menoscabo" a la calidad de monumentos de estas piezas artísticas, razón por la cual otorgó el permiso sin reservas, lo cual, podría interpretarse, habla bien de su apertura de criterio. ¿O será por la pasividad que critica Blanca Garduño?

Isolda Pineda Kahlo pidió que el Instituto Mexicano de la Propiedad Industrial tomara medidas precautorias respecto de los productos, asegurando aquéllos que ya circulaban en los comercios. Al final, Godven International se declaró en quiebra y señaló como responsable a Pineda Kahlo por los comentarios adversos que ésta hizo en los medios de comunicación sobre los cosméticos. Al parecer de Godven Internacional, era culpa de Pineda Kahlo que las ventas del perfume El carácter de su esencia se vinieran abajo y provocaran que la empresa quebrara ${ }^{18}$.

\section{FRIDA SE FUGA A LA REALIDAD VIRTUAL}

El anterior es un caso en el que la reproducción de imágenes "protegidas" pudo ser frenada por quienes reclamaron tener derecho sobre ellas.

${ }^{15}$ Hasta en la tienda de regalos del Palacio de Bellas Artes, donde se venden corbatas y mascadas con reproducciones no autorizadas por el INBA. Ello puede saberse porque, en todos los productos autorizados por el INBA está una leyenda que se pronuncia en este sentido.

${ }^{16}$ Hernández, op. cit.

${ }^{17}$ Las cursivas son mías.

${ }^{18}$ Ver Alejandro Hernández, "Quiebran por perfumes de Frida», Reforma, 27 de marzo de 2003 .

DA-2005, núm. 273. MIRIAM GRUNSTEIN. 8. La cultura va al mercado. El patrimonio cultu... 
En este caso, fue posible hacer valer un derecho sobre algo aparentemente tan etéreo como un nombre. ¿Podría Pineda Kahlo impedir que alguien nombrara a su hija Frida Kahlo; y que ésta a su vez nombrara a su hija de la misma forma y así hasta el infinito? Ciertamente, aquí se trata de otro supuesto, pues la ley de propiedad industrial prohíbe el uso no autorizado del nombre como marca pero no como aquél atributo inalienable de la persona humana. En tal caso, quien al nacer le fuera dado el nombre "Frida Kahlo" sería, por más extraño que suene, otra Frida Kablo, tan auténtica como la primera. Si corriera con suerte, la otra Frida podría ser incluso más célebre y menos atormentada que la otra. La recién nacida Frida Kahlo es una pentatleta en potencia cuyo nombre correrá por la supercarretera global sin que nada ni nadie pueda detenerlo. Es posible que Frida Kahlo, la corredora de clase mundial, sea muy popular, incluso más que la pintora, y que su nombre quiera ser utilizado en una línea de ropa deportiva, para una marca de desodorantes o como signo distintivo para un ungüento contra el pie de atleta. ¿Podrían entonces oponerse Pineda Kahlo, por tener un derecho sobre el nombre de la pintora; el Fideicomiso Frida Kahlo y Diego Rivera por ser los titulares de los derechos de autor sobre la obra de la pintora; y el Instituto Nacional de Bellas Artes por tener facultades para defender y difundir la obra, declarada patrimonio artístico de la nación? ¿Podrían Teresa del Conde y Raquel Tibol condenar que el uso del nombre, ya no de la pintora, sino de su homónima, es una vulgarización del arte?

Aparte de las ficciones, existen casos reales en los que imágenes protegidas por legislaciones nacionales circulan vertiginosamente en medios difícilmente controlables como son los digitales. En el marzo de 2001, llegó esta carta, en versión bilingüe, a la dirección de asuntos jurídicos del Instituto Nacional de Bellas Artes ${ }^{19}$ :

“Te quiero alertar de una violación aparente de derechos de autor concerniente al trabajo de Frida Kahlo.

La Universidad del Sur de California (USC) tiene una división llamada "The Annenberg Center for Communications" (...) Como parte de las actividades de Annenberg, la profesora Marsha Zinder ha creado un número de diferente (sic) CD ROM y trabajos de internet.

Uno de los trabajos creado (sic) por Marsha Zinder se titula RUNAWAYS, que es un prototipo para un juego de CD ROM y de un juego de interner. Como parte del juego, los jugadores encuentran algunas pinturas de Frida Kahlo.

${ }^{19}$ Se trata de un comunicado anónimo dirigido a Lilliane Corona, del Instituto Nacional de Bellas Artes. Dicha persona me proporcionó copia la carta sellada con acuse de recibo por parte de la Dirección de Asuntos Jurídicos del Instituto Nacional de Bellas Artes, con hecha del

DA-2005, núm. 273. MIRIAM GRUNSTEIN. 8. La cultura va al mercado. El patrimonio cultu... 
Esas pinturas no son usadas solamente en este proyecto, hasta donde se, sin permiso, sino que también son alteradas. La cara de Frida Kahlo ha sido borrada y, usando tecnología computarizada, otras caras han sido sobrepuestas en su trabajo (...)".

RUNAWAYS ha sido mostrado públicamente en varios contextos educativos. El productor plantea eventualmente vender el juego al público (...).

Yo no tengo nada que ver con este proyecto, me comunico confidencialmente con usted debido a que creo firmemente en los derechos de autor y no me agrada ver ningún tipo de violación, en especial si se trata del Centro de Comunicaciones de Annenberg el cual es un centro que cuenta con los recursos para pagar los derechos sin problema alguno (...)."

La carta venía acompañada del folleto promocional del juego que lo describe. Runaways es un juego de la creación de la profesora en medios de comunicación y productora Marsha Zinder y del cineasta de documentales y autor de libros para niños Mark Jonathan Harris. El juego, según el folleto, desafía los límites de los juegos electrónicos convencionales tanto en forma como en contenido. Mientras que el objetivo evidente del juego es algo tan simple como el ejercicio detectivesco de seguir los pasos de una joven fugitiva de origen mexicano llamada Rita, los objetivos subyacentes del mismo buscan la transformación de la visión de los adolescentes en cuanto a cuestiones de sexualidad, cultura y género. Explica Kinder que los juegos son una forma especial de narración con objetivos explícitos y un conjunto de reglas arbitrariamente impuestas. Ellos presentan una magnífica oportunidad para "negociar" la relación entre las reglas sociales y el grado de libertad que tienen los jugadores en cambiarlas ${ }^{20}$.

Para ello, para el papel de la fugitiva, Kinder creó un prototipo llamado Rita Rodríguez que huye de casa por revelarse de sus padres quienes se oponen a su relación con su novio chino quien, además, es mucho mayor que Rita. Kinder menciona que, al elegir el prototipo, ella y Harris buscaron una historia que tuviera un potencial importante de impacto visual, razón por la que eligieron personajes chinos y mexicanos. "Queríamos poner énfasis no sólo en los problemas, sino en la riqueza del patrimonio cultural. Más específicamente, queríamos demostrar cómo los murales en Los Angeles son parte del patrimonio artístico de México." En su periplo, Rita huye a México donde descubre la obra de Diego Rivera, José Clemente Orozco y David Alfaro Siqueiros. Al seguirla en su fuga, la vemos contemplar las pirámides de Teotihuacan, donde ella y su novio descubren "conexiones provocativas" entre el arte chino y mexicano. Rita y su novio chino son artistas de video y comparten la pasión el arte como medio para explorar su propia identidad personal, sexual y cultural.

${ }^{20}$ Ver switch.sjsu.edu/web/v5n2/runaways.html.

DA-2005, núm. 273. MIRIAM GRUNSTEIN. 8. La cultura va al mercado. El patrimonio cultu... 
Por lo dicho en el folleto, no es muy claro cómo el juego revoluciona las concepciones de los jóvenes en tanto a su visión de la cultura, de su relación frente a la autoridad y de las relaciones de género. Algunas gráficos del juego, incluidos en el folleto, muestran la cara de la joven "latina" que se transforma, a manera de metamorfosis, en el rostro de un joven oriental. Rita la mexicana deviene en su novio chino. Ello podría interpretarse como el cruce sugerido entre las barreras de la raza y el género. La fuga de Rita hacia donde no pueda ser detenida por el autoritarismo racista de sus padres podría ser interpretado como una invitación a los jóvenes a cuestionar y subvertir las reglas de su entorno sociocultural. El periplo onírico de Rita se desenvuelve en un laberinto en cuyas paredes aparecen rostros cambiantes y otras imágenes que no llegan a definirse del todo. Sin duda, estas imágenes, si es que no son idénticas, se parecen mucho a ciertos autorretratos de Frida Kahlo, con la diferencia de que las caras, como dice la "denunciante" en su carta al INBA, han sido cambiadas. Así, cualquiera podría pensar que, al diseñar el juego, Kinder y Harris, no sólo pensaron en proponer a los jóvenes subvertir una serie de reglas, sino que ellos mismos decidieron violar otras cuantas. El gran parecido que guardan las imágenes del juego con las pinturas originales de Kahlo hace pensar que a los autores también les atrajo la posibilidad de extralimitarse, de subvertir y violar los derechos intelectuales sobre las obras de arte que reprodujeron sin permiso.

\section{"EL RESPETO A LA HAMBURGUESA AJENA ES LA PAZ"21, OAXACA VS. RONALD MCDONALD}

Por el Zócalo de la Ciudad de Oaxaca de Juárez pasan todo tipo de personas. Al son de la marimba, en una tarde de domingo de agosto, deambula por ahí una familia oaxaqueña de clase media. La hija mayor, de 17 años, podría traer puesto un pantalón de mezclilla, a la cadera, de donde sale un torso delgado apenas cubierto por una camiseta que le llega al ombligo. Sobre la camiseta podría estar estampado el nombre de una banda de rock. El hermano menor, como de catorce años, podría vestir bermudas color kaki, holgadas; calza unos tenis con foquitos en la suela que echan chispas con cada paso. Lleva puesta una camiseta verde y amarilla con la palabra "Ronaldinho" estampada en la espalda. La señora viste una falda de mezclilla a la rodilla, una camisa de algodón blanca de

${ }^{21}$ Palabras de un joven oaxaqueño cuando se le preguntó su opinión sobre la prohibición de establecer un McDonalds en el Zócalo de la ciudad Oaxaca.

DA-2005, núm. 273. MIRIAM GRUNSTEIN. 8. La cultura va al mercado. El patrimonio cultu... 
manga corta, algo bordada, y calza alpargatas españolas. El señor trae puestos pantalones de mezclilla y una camisa deportiva de Tommy Hilfiger.

Después de dar una vuelta por la plaza, la familia se acomoda en una mesa en una pequeña gelateria italiana, bajo los arcos del portal Benito Juárez, que tiene vista a la catedral. Junto a ellos, en el negocio contiguo, están sentados unos alemanes, que beben cerveza Corona con limón en tarros congelados; se les ve hambrientos cuando el mesero les trae un plato inmenso, surtido de mole negro, frijoles, cecina, quesillo y chapulines. Una pareja de americanos que pasa junto a ellos le pregunta al mesero que trae la bandeja, en pujante y bien intencionado español, si conoce algún restaurante vegetariano. El mesero sacude la cabeza, dice "no" en voz baja, y les sonríe sin mirarlos. Los americanos siguen su camino y se detienen en un puesto de textiles bordados de todos los colores que dos mujeres con cabello trenzado, huipil bordado y grandes arracadas de filigrana de oro atienden desde el piso. Por el aire corre el murmullo de mil lenguas, la sombra de un avión roza las naves de la inmensa Catedral de cantera verde.

Allí, en el Centro Histórico de Oaxaca, Patrimonio Cultural de la Humanidad, Mc Donald's, la afamada cadena de restaurantes de hamburguesas, quiso abrir un local. Las razones de negocios sobraban: el Zócalo de Oaxaca es seguramente uno de los puntos más transitados de la ciudad y los comensales que acuden a los arcos abarcan todos los tipos sociales y culturales. Sin duda, entre tantas personas habría más que las suficientes para hacer rentable, muy rentable, el negocio de los afamados "Arcos Dorados.” Así, pues, McDonald's, como cualquier otro interesando, inició el trámite ante el ayuntamiento para obtener la licencia para abrir el restaurante.

La respuesta a la iniciativa de McDonald's no tardó en llegar. Francisco Toledo, pintor, escultor, grabador, fotógrafo, promotor cultural y presidente del Patronato pro Defensa y Conservación del Patrimonio Cultural y Natural de Oaxaca (Pro-Oax), cuyo liderazgo moral logra conmover las pasiones de muchos oaxaqueños, inició una campaña de protestas en contra de la apertura del establecimiento. Así se organizó la "tamaliza" a la que se sumaron miles de personas en un acto de repudio cuyo objeto no es tan fácil precisar.

Al clamar "tamales sí, hamburguesas no", ¿contra qué protestaban algunos oaxaqueños? Suponiendo que fuera la apariencia del establecimiento, ello hubiera tenido arreglo con algo tan sencillo como el apego de la empresa a los lineamientos de apariencia urbana aplicables a todos los establecimientos ubicados en una zona patrimonial. Con algo de imagiDA-2005, núm. 273. MIRIAM GRUNSTEIN. 8. La cultura va al mercado. El patrimonio cultu... 
nación, se pudo evitar que esperpénticos bancos de formica naranja, o la faz del payaso cairelado, asaltaran frontalmente el paisaje colonial. Con todos los recursos que existen hoy para los diseñadores y arquitectos, se pudo haber encontrado la forma para reducir las discrepancias estéticas entre el establecimiento y su entorno. ¿Era, entonces, la comida? ¿Es superior el valor nutritivo de un tamal oaxaqueño al de una hamburguesa? ¿La calidad de los productos? ¿La limpieza? Aquí hay una gama intrincada de susceptibilidades que tienen que ver de mucho a nada con el impacto visual del establecimiento en el Zócalo. Algo de la presencia de McDonald's en el Zócalo de Oaxaca irritaba mucho más que la suma de la hamburguesa, papas y refresco.

Sobre ello en específico, apareció esta nota editorial ${ }^{22}$ :

"Dos dogmas religiosos se encuentran sumamente preocupados por la propagación de valores ajenos a su fe. Por un lado, la Iglesia Católica mexicana ha manifestado una consternación por la exhibición de una película. La premisa del guión ofende los principios de la jerarquía eclesiástica: un hombre se enamora de una mujer. El agravio consiste en que la mitad masculina del romance usa una sotana como uniforme de trabajo.

En los territorios de la fe ideológica, varias figuras clave de la cultura nacional han manifestado, en cartas a la prensa, su rechazo a la inauguración de un conocido restaurante de hamburguesas en el zócalo de Oaxaca. La cadena de comida rápida más grande del mundo no se caracteriza por la exquisitez arquitectónica de sus establecimientos, ni por la sofisticación de su decorado interior. Los letreros de plástico rojo con letras amarillas, sobre un edificio colonial, serían un desastre estético para uno de los espacios públicos más hermosos de México. Sin embargo, el merendero del payaso pelirrojo tendrá que ajustarse a los reglamentos de desarrollo urbano y protección del patrimonio arquitectónico. Las conciencias preocupadas por la presencia del restaurante, no invocan argumentos estéticos para impedir su autorización. Sus preocupaciones son de otra índole.

En la carta de protesta contra las hamburguesas se pide la intervención de “autoridades federales, estatales y municipales" para impedir la instalación de un establecimiento que "promueve una cultura alimentaria nociva para la salud, ajena a nuestras tradiciones." Cada dogma tiene sus propias rutas para llegar al infierno. El personaje literario de un sacerdote que se deja tentar por las debilidades de la piel es una afrenta inadmisible para los obispos nacionales. Para los intelectuales mexicanos, la cadena de los arcos dorados es la manifestación gastronómica del mal encarnado de nuestro tiempo. La globalización le ha dado nuevos bríos a la vieja izquierda. Toda causa progresista requiere de un enemigo contra quien luchar. Defender la calidad y el sabor de una hamburguesa es una causa perdida. Para un comensal sofisticado, la fast food es un insulto al paladar. Sin embargo,

${ }^{22}$ Juan Pardinas, «El crimen de Ronald McDonald», Reforma, México, Distrito Federal, 16 de junio de 2002.

DA-2005, núm. 273. MIRIAM GRUNSTEIN. 8. La cultura va al mercado. El patrimonio cultu... 
tener mal gusto es un derecho jurídico con rango constitucional. La libertad de expresión nos garantiza el derecho de ver en el cine lo que se nos antoje y comer la basura que más nos plazca. Los cardenales Sandoval Iñiguez y Norberto Carrera lanzaron su cruzada para salvar a la sociedad mexicana de la inmoralidad de una película. Monsiváis y Poniatowska nos quieren proteger de los pecados ideológicos de comer una hamburguesa. Para la escuela del Padre Amaro, el guionista puede escribir una trama que agravie a ambos credos $y$, de paso, asegure una jugosa taquilla: un cura noviero que invita a sus conquistas a un McDonalds en Oaxaca."

\section{La cuestión fue finalmente zanjada cuando el ayuntamiento por fin} negó la licencia a McDonalds ${ }^{23}$ :

“El Presidente Municipal Gabino Cué Monteagudo invitó a McDonald's a instalarse en un espacio distinto al del centro histórico y aseguró que, a condición de que respete el patrimonio, cualquier empresa puede invertir en Oaxaca.»Esta decisión nos va a servir mucho. Oaxaca va a dar el ejemplo de que hay espacios que deben respetarse, no sólo por estas cadenas de restaurantes que vienen de fuera, sino también por nosotros. Ojalá que esta sea una lección para todos, que el centro histórico se preserve y dé una imagen de lo maravilloso que fue en una época», señaló el artista.

Ayer al mediodía, los concejales del Cabildo conocieron el dictamen de la omisión del centro histórico, donde se niega la licencia para el McDonald's. De los 20 asistentes, 18 votaron a favor de dicho dictamen, con la abstención de dos panistas y la ausencia de dos priistas. «Dictamen: (punto) único. No ha lugar para conceder autorización del uso de suelo solicitado por la C. Josefina Díaz Huergo de Cuetos para el establecimiento de un restaurante de comida rápida, perteneciente a la franquicia McDonald's», se señaló.

La razón aducida fue que el área donde se pretendía instalar el McDonald's, un local en los portales del zócalo que antes había albergado a la tienda «El mundo elegante», tenía un área de mil 219 metros, cuando la normatividad permitía sólo un área de 500 metros cuadrados. Otro motivo fue la necesidad de conservar el patrimonio. «La permisividad de dicho establecimiento trastocaría el espíritu del reiterado reglamento y la función simbólica del conjunto zócalo-alameda-catedral, pertenecientes al centro histórico de la ciudad capital, a cuyo alrededor gira la sociedad oaxaqueña», dicen los considerandos del dictamen.

La petición de licencia para el McDonald's fue promovida por la dueña del local, Josefina Díaz Huergo, el 3 de julio de este año. El 18 de agosto, Toledo organizó una tamaliza de protesta en el zócalo, a la que siguieron diversos pronunciamientos y la reunión de 10 mil firmas de ciudadanos que se opusieron al proyecto, hasta llegar a la negativa del Ayuntamiento hecha oficial este martes. «Yo esperaría y apelaría a la empresa para que, si ya hay una decisión del Cabildo,

${ }^{23}$ Ver http://www.foros.gob.mx/read.

DA-2005, núm. 273. MIRIAM GRUNSTEIN. 8. La cultura va al mercado. El patrimonio cultu... 
si existe un sentir ciudadano para que se preserven estos espacios, por respeto a nuestra cultura y tradiciones creo que no les costaría nada buscar otro lugar donde instalarse», dijo ayer Cué Monteagudo.

En entrevista, Toledo descartó organizar una nueva tamaliza para festejar la negativa de la licencia a McDonald's, para no hacer escarnio de una empresa a la que «parece le han ido mal los negocios». Agregó que había esperado que la trasnacional, como un gesto de «buena fe» hubiera renunciado a sus planes antes de que tuvieran lugar las movilizaciones ciudadanas.

Rodeado de los miembros de Pro-Oax, Toledo confesó que no durmió bien debido a la tensión, y en tono de broma señaló que, de haber ganado McDonald's, «nos hubiéramos ido a comer al centro».En conferencia de prensa, el artista dijo entre risas que no se veía a sí mismo como un líder ciudadano. «Yo quiero pintar, hacer mi trabajo; como líder no la hago, no tengo carácter para estar en estas lides. Creo que debo ya quedarme un poco en casa, pero urge que vengan otros. Pienso que hay sensibilidad, el problema es el miedo a la represión, pero la sociedad civil está ganando espacios para hacerse oír», señaló."

Toledo tiene razón: hay sensibilidad y hay miedo a la represión. La cuestión aquí es de dónde viene la represión y quién la sufre. Desde el punto de vista jurídico, la cuestión pudo haber llegado a los tribunales federales y hay razones para pensar que éstos le hubieran concedido el amparo de la justicia a la empresa, pues se le privó de un derecho mediante un par de argucias técnicas sobre el tamaño del local aunadas a apreciaciones muy arbitrarias como que el establecimiento atentaría "contra el espíritu del reglamento y contra el conjunto simbólico del conjunto Zócalo-Alameda-Catedral.” Tal como figura en la nota de Juan Pardinas, "tener mal gusto es un derecho jurídico con rango constitucional. La libertad de expresión nos garantiza el derecho de ver en el cine lo que se nos antoje y comer la basura que más nos plazca." Es predecible que la justicia federal hubiera resuelto proteger al payaso Ronald, con tal que éste se sujetara al ámbito real de regulación que le corresponde. La creación de establecimientos comerciales en zonas patrimoniales es un ámbito regulado dotado de un sentido claro: la protección de los paisajes especialmente valiosos para las comunidades, locales, nacionales e internacionales. Dentro de este ámbito de regulación, se deben de trazar líneas lo suficiente claras para que Ronald y sus amigos puedan convivir con otros en sociedad, si ésta última pretende ser en lo mínimo tolerante.

A propósito de este suceso, el escritor oaxaqueño Fernando Solana Olivares menciona, «es increíble la capacidad de Toledo de mover la conciencia pública, no en balde juega un papel predominante en el imaginario del país. Mi objeción es que la energía social que logra convocar debería dedicarse a la crítica de lo real. Para Toledo a veces cuentan más los moDA-2005, núm. 273. MIRIAM GRUNSTEIN. 8. La cultura va al mercado. El patrimonio cultu... 
numentos que los hombres de carne y hueso ${ }^{24}$." Señala, además, que "el centro histórico lo que está pasando a todo el Estado y que por razones simbólicas, geográficas e históricas se concentra precisamente en el centro. Los centros históricos son los resonantes de la vida real de esa ciudad, por lo cual el problema del centro histórico no se va a resolver con esas defensas dudosas sobre la condición sacra del espacio y la prohibición a algunas empresas para establecerse en la capital del Estado, como el ya citado caso McDonald's ${ }^{25}$."

\section{LA LEY DE LA SELVA: LA TRISTE HISTORIA DE UN CASINO}

Es difícil controlar la expansión del flujo de obras artísticas ilícitamente reproducidas y más aún cuando en tiempos cuando la tecnología rompe con toda noción de los controles centralizados de los estados nacionales. Hoy día, las imágenes de los patrimonios culturales de las naciones se arrojan a la supercarretera cibernética en donde pasan ante millones de ojos. El mundo se ha vuelto de copias y la satisfacción que ellas brindan merma la nostalgia por los originales. También, es difícil acordonar las zonas patrimoniales de todo influjo "extraño" sin que pueda surgir algún reproche sobre el daño a las libertades que esto implica. La sacralización de una zona patrimonial puede llevar, en casos extremos, a su deserción.

Ahora bien, el caso contrario sucede cuando un inmueble precioso es descuidado a tal grado que, al final, no queda más remedio que ponerlo en el mercado a valor de deshecho para que ésta genere alguna renta.

¿Fue esto lo que sucedió con el hotel Casino de la Selva ${ }^{26}$ ? Al momento de su demolición habían pasado años, décadas tal vez, desde su auge como hotel de $\operatorname{moda}^{27}$ hasta que una mañana del verano de 2001,

${ }^{24}$ Ver www.juridicas.unam.mx/publica/librev/rev/derycul/cont $/ 9 / \mathrm{mis} / \mathrm{mis} 9 . \mathrm{pdf}$.

25 Ibid.

${ }^{26}$ Señala Humberto Musacchio en su Diccionario Enciclopédico de México que el antiguo hotel Casino de la Selva de Cuernavaca «encierra una de las pinacotecas más importantes del país». Y en efecto, en su interior hay o había murales de Benito Messeguer Villoro, de Gabriel Flores, de Jorge González Camarena (su mural se llamó Coatlicue-1964), de Mario Orozco Rivera, del Dr. Atl, de José Reyes Meza, de José Renau Berenguer (España hacia América-1944 a 1950), y otros.

${ }^{27}$ Dice Octavio Rodríguez Araujo: "No conozco bien la historia del Casino de la Selva, que se ha puesto de moda en estos días por el atropello y la vejación de que está siendo objeto. Sabemos que lo compró Manuel Suárez (el padre de Lilia y abuelo de Lilia Rossbach) a Abelardo L. Rodríguez después de diez años de abandono y de haber sido casino. Los Suárez lo reconstruyeron durante dos o tres años y lo convirtieron en hotel con una superficie de alrededor de 90 mil metros cuadrados incluidos los jardines. Ahí construyó Félix Candela la DA-2005, núm. 273. MIRIAM GRUNSTEIN. 8. La cultura va al mercado. El patrimonio cultu... 
DA-2005, núm. 273. MIRIAM GRUNSTEIN. 8. La cultura va al mercado. El patrimonio cultu...

salió la noticia de que lo demolían para construir en su lugar una tienda gris y rectangular de cacofónico nombre: COSTCO. Para algunos mexicanos, la noticia fue recibida con simple nostalgia, pues el hotel contenía los recuerdos de quienes pasaron vacaciones inolvidables en los jardines, entre helechos selváticos, devorados por los moscos, corriendo de lado a lado y dando chapuzones en la alberca. Dentro de este grupo de nostálgicos, tal vez hubiera un puñado que supieran de la cúpula de Félix Candela, de los murales de Renau, Icaza y Reyes Meza, de la novela de Lowry; que el hotel estaba situado en una zona arqueológica y que los jardines selváticos del mismo eran parte del patrimonio ecológico de México. Y, sin embargo, el Hotel Casino de la Selva fue patrimonio sentimental de muchos. Si es así, ¿por qué el abandono de los que lo amaban?

Ello se explica, en parte, porque el hotel era de propiedad privada y al público no le competía su conservación, como a su dueño no le compete la conservación de la casa de los huéspedes que tanto amaron el hotel. Es cierto que, si yo abro mi casa al público, no por ello mi casa se vuelve de propiedad pública. ¿Y si contuviera murales hermosos? ¿Y cúpulas fotografiadas en libros de arquitectura moderna? Tampoco. En un sentido estrictamente jurídico, una casa y un hotel de propiedad privada están en la misma situación. Tanto el hotel como mi casa tendrían un dueño y cada uno podría hacer con lo suyo lo que mejor le parezca.

¡Un momento!, dirían algunos. El gobierno sí fue dueño del hotel. Los herederos del dueño original del hotel, Marcos Manuel Suárez, vendieron los $94,000 \mathrm{~m}^{2}$ al grupo SIDEK-SITUR, para realizar un proyecto turístico. Luego, en el año 2000, el grupo realizó una dación en pago a la Tesorería de la Federación (por EEUU \$ 63,749,093.47) por incumplimiento en sus obligaciones fiscales. Fue entonces que la Tesorería de la Federación decidió enajenarlo y solicitó a la Comisión Nacional de Avalúos de Bienes Inmuebles-CABIN realizar el avalúo correspondiente. "El predio fue tasado en 1, 047 pesos el $\mathrm{m}^{2}$, que equivale aproximadamente a una tercera parte del valor comercial promedio de terrenos simi-

Capilla abierta (1959, junto con Guillermo Rosell y Manuel Larrosa) que iba a ser un templo para todas las religiones, pero que no fue autorizada por las autoridades. Más adelante la Capilla habría de convertirse en restaurante, como el de Xochimilco construido en 1957, discoteca, bar y teatro. En el Casino de la Selva vivieron personajes famosos. Uno de ellos fue el escritor inglés Malcolm Lowry, quien se hospedara en la habitación 212 del hotel donde escribió, alternada con el viejo bar, la primera versión de Bajo el volcán en 1947. Carlos Monsiváis también vivió ahí para escribir uno de sus libros, según me cuenta Lilia Suárez. Amparo Montes, entre otras de nuestras divas, nos deleitó por años en el nuevo bar, que estaba a la entrada del hotel." Ver de este autor, su artículo en diario La Jornada, Ciudad de México, 19 de julio de 2001.

DA-2005, núm. 273. MIRIAM GRUNSTEIN. 8. La cultura va al mercado. El patrimonio cultu... 
lares en el centro de Cuernavaca, pasando por alto el acervo cultural que contenía el inmueble del Casino ${ }^{28}$."

Desde ahí, la suerte del predio estaba echada. La Tesorería de la Secretaría de Hacienda y Crédito Público entregó el predio al Fideicomiso Liquidador para que lo enajenara; y, una vez publicada la licitación en $E l$ Diario Oficial de la Federación, mas no en los periódicos locales de Morelos, ésta fue celebrada y quedó como ganador el Grupo Costo-PriceComercial Mexicana. Este grupo adquirió el hotel, en el año 2001, por EEUU \$10 millones, una sexta parte del valor por el que lo recibió la Federación ${ }^{29}$.

Hasta aquí en lo narrado no hay indicios evidentes de ilicitud en el proceder, ni por parte de Costco, ni de las autoridades. Efectivamente, la CABIN no le dio valor artístico a los murales, cosa que tampoco hicieron los dueños del hotel al realizar la dación en pago. De hecho, los murales no estaban inscritos en el registro del patrimonio inmueble del INBA. Por otra parte, José Luis Caballero, abogado externo de Costco, en respuesta a un correo electrónico, que le envié preguntándole por el estado del predio al momento de la compraventa por Costco, afirmó que al momento de su adquisición por Costco, los murales se encontraban gravemente dañados por la humedad, por el guano de murciélago y por el vandalismo.

En este escenario, "la demolición de los edificios de Candela por parte de Costco fue realizada entre el 12 y el 14 de julio de 2001, con la autorización del Municipio de Cuernavaca (07.09.02). En todo caso, fue un hecho perpetrado contra la expresa recomendación de CONACUL$\mathrm{TA}^{30}$ y con su protesta posterior, aunque jurídicamente Costco tenía derecho a decidir en última instancia por ser la propietaria del predio (...) En cuanto a los murales, al no estar registrados, no podían ser protegidos." El registro hubiera podido ser realizado a petición de los sucesivos propietarios. Es decir, los descendientes del dueño original (Manuel Suárez), la empresa SEDIK-SITUR o la misma Costco ${ }^{31}$.

Pero nada de esto se hizo y lo que siguió a la demolición fue el escándalo que despertó a México, ya demasiado tarde, a la realidad del Casino. En lo que toca a las acciones del gobierno, es cierto que el inmueble no

${ }^{28}$ Ver «El Casino de la Selva». Informe Analítico con recomendaciones. The International Ombudsman Centre for The Enviroment and Development, p.7. www.omced.org

${ }^{29}$ Ibid., p.8.

${ }^{30}$ Aunque la conservación de monumentos sea de la competencia del INBA.

31 The International Ombudsman Centre for The Environment and Development, op cit., p. 8 .

DA-2005, núm. 273. MIRIAM GRUNSTEIN. 8. La cultura va al mercado. El patrimonio cultu... 
estaba protegido, pero también lo es la facultad del INBA, conforme al artículo 34-B de la Ley Federal sobre Monumentos, de emitir una declaratoria de emergencia "cuando exista el riesgo de que se realicen actos de efectos irreparables sobre bienes muebles o inmuebles con valor estético relevante."

Nada de esto se hizo, desatándose el pandemonium. Inmediatamente después del anuncio de la demolición, se organizó el Frente Cívico Pro Defensa del Casino de la Selva, asociación ciudadana de origen morelense que hasta hoy se ha encargado de interponer o canalizar al menos 17 denuncias ante instancias federales y locales, contra funcionarios de Costco y otros responsables en la compra-venta y demolición del inmueble. Además, han llamado la atención de los medios diversos actos de desobediencia civil, incluyendo un acto de nudismo, organizado, si bien no protagonizado, por la actriz Ofelia Medina, en el recinto de la Cámara de Diputados.

Es llamativo notar cómo las ramas del Frente se han extendido, desde Cuernavaca, hasta puntos de profunda revuelta en el país. Basta entrar a la página de internet ${ }^{32}$ del Frente para percatarse de la participación de algunos personajes coloridos de la escena política nacional, desde el Subcomandante Marcos hasta el Mosh, renombrado "huelguista" universitario que resurgió de sus cenizas para protestar por el hotel. "Por su parte, el Consejo Ciudadano para la Cultura y las Artes de Morelos A.C.., parte del Frente Cívico, canalizó directamente dos denuncias, solicitando la suspensión de obras y sanciones para los responsables. Flora Guerrero, unas de las líderes más representativas de Frente Cívico, interpuso por su propio derecho, un recurso de revisión y un juicio contencioso y conjuntamente con el Diputado Jorge Messeguer una denuncia popular. De la misma Cámara de Diputados, el Diputado Elías Martínez Rufino, del grupo parlamentario del Partido de la Revolución Democrática, se derivó un Punto de Acuerdo que exhortó al Presidente de la República para expropiar el terreno del hotel y expeditar la declaratoria de monumento artístico, histórico y arqueológico. En cuanto a los demás actores, Costco no ha iniciado denuncia o demanda alguna en contra de nadie ${ }^{33}$ ", fuera de las detenciones derivadas de los ilícitos cometidos durante los actos de desobediencia civil.

Según declaraciones del INBA, CONACULTA y Costco, "los murales están siendo rescatados con inversión de la empresa para su entrega a la ciudadanía." Para ello, Costco celebró un contrato de donación, con

${ }^{32}$ Ver www.procasino.com.mx.

33 The International Ombudsman Centre for The Environment and Development, p. 38. DA-2005, núm. 273. MIRIAM GRUNSTEIN. 8. La cultura va al mercado. El patrimonio cultu... 
fecha 10 de octubre de 2001, a favor del Municipio de Cuernavaca, en cuyo clausulado el INBA se obligó al retiro y restauración de los murales a costa de Costco. Sin embargo, a siete meses de la firma del contrato, en junio de 2002, el INBA aún no había retirado los murales, por lo que José Luis Caballero, el ya mencionado abogado de Costco, "advirtió que se agotarán los procedimientos extraoficiales para que el INBA cumpla con la función para la que fue 'contratado', pero recordó que existen diversos recursos legales (...) como exigir la forzosa realización de lo pactado en el documento ${ }^{34}$. Una vez restaurados los murales, Costco manifestó su voluntad de construir un Centro Cultural anexo de $7.000 \mathrm{~m}^{2}$, en el terreno donde se ubicaba el hotel, anexo a las tiendas Costco, MEGA Comercial Mexicana y el Restaurante California. En dicho Centro Cultural se propuso la instalación de la Colección Gelman-USA “(obtenida en Comodato por cinco años por Costco), que incluye cuadros de Rivera, Orozco, Kahlo, Siqueiros y otros grandes pintores mexicanos"35. Además, Costco se comprometió a restituir la estructura paraboloide hiperbólica de Félix Candela y uno de los bungalows como muestra de lo que fue el Hotel Casino y van a habilitar una plaza-foro para artes escénicas ${ }^{36}$."

De todos los escenarios posibles, no parece reprochable que una cadena de supermercados haya accedido a patrocinar un centro cultural, en particular porque Costco no es, por vocación, un patrono natural de las artes, ni fue el principal responsable de la lamentable pérdida del hotel. Uno se pregunta: ¿dónde estaban los herederos de Suárez, mientras se derrumbaba? ¿Dónde estaban las autoridades locales y federales que sabían de la existencia del hotel? ¿Dónde estaban los pintores de los murales durante todos estos años? Ahogado el niño, José Reyes Meza, único sobreviviente de los muralistas del hotel, y autor del "Mural de la Cultura Indígena" afirmó ante los medios que los nuevos dueños del Casino de la Selva "pueden hacer con lo que les dé la gana con las pinturas ${ }^{37 "}$ ", explicando que "yo ya hice mi parte: defendí mi obra. Vine con la esperanza de que se me permitiera hacer uso de los derechos de autor que me concede la ley. Como ni las autoridades ni los nuevos dueños me permitieron participar en su preservación, que hagan ahora lo que quieran. Si la co-

${ }^{34}$ Ver Antonio Bertrán, "Estudian demandar al INBA si falla diálogo», en Reforma, 24 de junio de 2002.

${ }^{35}$ Hoy día ya está abierto el Centro Cultural Muros, donde se exhibe la colección Gelman.

36 The International Ombudsman Centre for The Enviroment and Development, p. 8.

37 Ver Carmen Álvarez, "Descarta Reyes Meza luchar por su obra», en Reforma, 10 de julio de 2001.

DA-2005, núm. 273. MIRIAM GRUNSTEIN. 8. La cultura va al mercado. El patrimonio cultu... 
munidad artística y gente de Cuernavaca los quiere defender, que los defienda. Yo ya cumplís."

\section{LA DEFENSA DEL VETERANO. EL TORO ES PATRIMONIO}

Un último caso hace sonreír por correr a contrario sensu a todo lo dicho hasta ahora. ¿Qué pasa cuando una ley de protección al patrimonio cultural, no sólo permite el uso del patrimonio cultural en la publicidad, sino que además consagra un emblema comercial al convertirlo en objeto del patrimonio cultural? A continuación se narra la historia de las andanzas de un gran Veterano: el Toro de Osborne ${ }^{39}$.

Desde que fue plantada en suelo de las carreteras españolas, la sombra monumental de este toro "ha despertado muchas pasiones y rara es la carretera que no cuenta con uno o varios ${ }^{40}$." A la vez, la figura que nació como una marca comercial, en el curso de su historia, ha hecho síntesis de una gama de personalidades y temperamentos españoles, lo cual ha hecho trascender a este particular signo distintivo de sus orígenes de mera marca comercial. Ello se hizo evidente con la prohibición de efectuar publicidad en vías interurbanas que se impuso en España ${ }^{41}$.

Mucho tuvo que ver la integración de España a la Unión Europea con la amenaza de perder al gran Toro andaluz, pues los acuerdos internacionales dieron lugar a reformas en la legislación nacional. La integración europea disparó la aplicación de la le Ley 25/1998, de Carreteras y Caminos, del 30 de julio y del artículo 88 del Reglamento General de Carreteras, del 2 de septiembre, que prohíben realizar publicidad, fuera de los tramos urbanos, en cualquier lugar visible de la carretera. Desde ese momento, diversos grupos de artistas, diseñadores, periodistas ${ }^{42}$ y figuras

\section{Ibid.}

39 "El toro de Osborne consiste en la silueta de un toro que nació fruto del encargo por parte de las Bodegas Osborne a la agencia AZOR para que efectuase un estudio de un símbolo representativo de su brandy "Veterano». El dibujo fue finalmente creado por Manuel Prieto, muy conocido por sus trabajos de grabados en la Fábrica Nacional de Moneda y Timbre, colocándose finalmente como valla publicitaria que, a lo largo de la segunda mitad del siglo XX, se generalizó por todas las carreteras de España.” Ver JAVIER A. MESTRE, "El nombre de dominio y la insuficiencia de las doctrinas actuales en materia distintiva", septiembre de 2001. www. dominiuris.com.

${ }^{40}$ http://www.alfa-redi.org/rdi-articulo.shtml?x=882.

41 Ibid.

42 "El toro de Osborne está ya unido al paisaje de España y no debemos apuntillarlo de mala manera, acercándolo con una maroma a un burladero del Boletín Oficial. El cachetero no debe acabar con la vida de este símbolo de Andalucía. Es como si condenaran a la chaquetilla DA-2005, núm. 273. MIRIAM GRUNSTEIN. 8. La cultura va al mercado. El patrimonio cultu... 
públicas de la sociedad española, se abocan a la defensa de la permanencia del toro en carreteras españolas. Varias consejerías de cultura correspondientes a las autonomías españolas pusieron en la mesa que la polémica sombra taurina fuera catalogada como bien cultural. "Más concretamente, la junta de Andalucía hace declaraciones en este sentido el día 13 de octubre de 1994, a través de su Consejería de Cultura ${ }^{43}$."

El tamaño del asunto del Veterano rebasó las dimensiones del Toro mismo. No es de sorprenderse, entonces, que la controversia del toro haya llegado, inclusive, al Tribunal Supremo español, el cual pronunció lo siguiente sobre la decisión contencioso-administrativa de sancionar al Veterano por su obcecación taurina a permanecer velando el paso de los viajeros por carreteras españolas:

"Cualquiera que sea la teleología de precepto sancionador, bien evitar el deterioro del paisaje, bien impedir que se distraiga al automovilista, no se contraría con la figura del toro. Es verdad, y ello no pasa desapercibido por esta Sala, que la imagen entra en el concepto europeo de publicidad (....) Si así no fuera, no se explicarían los gastos de mantenimiento de la valla que se costean por la entidad recurrente (...) Ahora bien, por encima de este factor en la pugna de dos intereses en juego, debe prevalecer, como causa que justifica su conservación, el interés estético o cultural, que la colectividad ha atribuido a la esfinge del toro $(\ldots)^{44 "}$

Dicho esto, quedaba claro que el pueblo español se había apropiado del signo distintivo de un Brandy. El Toro de Osborne dejó de ser propiamente el Toro de la casa Osborne para pasar al patrimonio colectivo de la comunidad que encauzó su defensa. Así, "El Congreso de los Diputados aprobó el 15 de noviembre de 1994 una proposición no de Ley pactada entre el partido popular y el PSOE que significó en la práctica la decisión de reconocer al TORO DE OSBORNE como patrimonio cultural y artístico de los pueblos de España, integrado en el paisaje, recomendando a las Administraciones Públicas que garanticen su permanencia

Corta del Tío Pepe a no poder usar el título de grandeza del embotellado sol de nuestra tierra. Aquí ha entrado una maldita fiebre europeísta, a la violeta que amenaza muchos símbolos patrios. ¿Qué ha ofrendado Gran Bretaña en el ara de la Comunidad Europea? ¿Ha obligado alguien acaso a los ingleses, en aplicación de europeas leyes de carretera, a circular por la derecha? Se sublevaría el Reino Unido de la Gran Bretaña si Europa así lo exigiera. Pues para nosotros este paisaje del toro en la lejanía es como circular por la izquierda, que es la mano del natural, cuando el sol atardeciendo le baja la mano y se le acerca a los pitones." Ver http:// www.antonioburgos.com/antologia/toros/re122289.htm.

43 http://www.osborne.es.

44 Ibid.

DA-2005, núm. 273. MIRIAM GRUNSTEIN. 8. La cultura va al mercado. El patrimonio cultu... 
en las carreteras españolas, en el marco de la Legislación de Conservación del Patrimonio Cultural y Artístico de los pueblos de España ${ }^{45}$."

Guste o no, el gran Veterano de Osborne, el Toro, salió victorioso de una batalla librada, no por los dueños de la marca y el signo, sino por la sociedad española. Aquí el comercio no consumió a la cultura.. Esta vez fue la cultura la que devoró una marca comercial. 
DA-2005, núm. 273. MIRIAM GRUNSTEIN. 8. La cultura va al mercado. El patrimonio cultu...

\section{Documentación Administrativa}

\section{3: SEPTIEMBRE - DICIEMBRE 2005}

MINISTERIO

DEADMINISTRACIONES

PUBBLICAS

Presentación: JOSÉ ROLDÁN XOPA

A) Fuentes $y$ organización administrativa José ROLDÁN XOPA: La irrupción de lo indigena en el derecho administrativo mexicano. Josefina CORTÉS CAMPOS: La descentralización de funciones y la eficacia de la Administración Pública. Sergio LÓPEZ AYLLÓN y Ali HADDOU RUIZ: Rendición de cuentas en los órganos reguladores autónomos. Algunas consideraciones sobre el diseño institucional de las autoridades reguladoras en México.

B) Garantias y control judicial Juan Carlos MARÍN GONZÁLEZ: Responsabilidad patrimonial del Estado en México.

Sergio LÓPEZ AYLLÓN: Democracia y rendición de cuentas: la ley mexicana de transparencia y acceso a la información.

Carlos ELIZONDO MAYER-SERRA y Luis Manuel PÉREZ DEACHA: Separación de poderes y garantías individuales: la Suprema Corte y los derechos de los contribuyentes.

C) Derecho administrativo especial

Carlos HERRERA MARTíN: El marco jurídico de la ordenación territorial en México. Una breve introducción. Miriam GRUNSTEIN: La cultura va al mercado. El patrimonio cultural en el tráfico comercial. 